\title{
Local scour protection using geocell for downstream of spillway
}

\author{
Enes GUL*, Talha SARICI** and Omerul Faruk DURSUN*** \\ *,**,***Faculty of Engineering, Department of Civil Engineering, Inönü University, Malatya, 44280, Turkey \\ **Corresponding Author: talha.sarici@inonu.edu.tr
}

Submitted: 13/06/2019

Revised: $\quad 15 / 11 / 2020$

Accepted: 22/11/2020

\begin{abstract}
Local scour is an important problem for hydraulic structures. The local scour in the downstream of dams causes problems such as the damage of the dam body stabilization, erosion of the slopes, and the submergence of the turbines. There are many studies investigating the local scour prediction of the downstream of the hydraulic structures, but in recent years, these studies have been replaced by studies of local scour reduction. The new idea of confining the bed materials using the geocell is becoming a popular solution. This solution can be especially used for the reinforcement of the soils. In this study, the preventability of the local scour downstream of chute channel by cellular confinement system, also known as geocell, was investigated. As a result, in case of using geocell, percentage reduction of the maximum scour depth up to $40.63 \%$ was observed.
\end{abstract}

Keywords: Chute channel; Geocell; Hydraulic structure; Local scour; Sandy soil; Spillway.

\section{INTRODUCTION}

The scour downstream of the hydraulic structures is an important problem in terms of material damage and fatal accidents. In particular, the scouring downstream of the dams can seriously compromise the dam stability. For this reason, local scour of the hydraulic structures had been widely investigated (Borghei \& Sahebari, 2010; Coleman et al., 2003; Farhoudi \& Shayan, 2014; Pagliara et al., 2011; Tuna \& Emiroglu, 2011). These researches presented various equations about the depth and location of the maximum local scour value (Balachandar et al., 2000; Champagne et al., 2017; Hoffmans \& Pilarczyk, 1995; Mason \& Arumugam, 1985; Nik Hassan \& Narayanan, 1985; Palermo \& Pagliara, 2018). In particular, the scouring downstream of the stilling basins had been investigated using the parameters, with and without a sill, different stilling basin geometry, and wide flow pattern (Farhoudi \& Shayan, 2014; Champagne et al., 2017; Palermo \& Pagliara, 2018; Koochak \& Bajestan, 2016; Oliveto \& Comuniello; 2009).

In recent years, several studies have been done to prevent the scouring downstream of the hydraulic structures (Amini et al., 2017; Heibaum, 2000; Khosravinia et al. 2018; Kim et al., 2000; Korkut et al., 2007; Li et al., 2006; Li et al., 2005; Radice \& Davari; 2014; Bejestan et al., 2015; Zarrati et al., 2010). When these studies are examined, it is observed that the idea of placing a bed sill into the bed material is a good solution (Ben Meftah \& Mossa, 2006; Grimaldi et al., 2009; Hamidifar et al., 2017).

On the other hand, geotextile usage is gradually increasing. Yun and Kim (2018) presented scour characteristics of artificial reef with different geogrid and soil type. The idea of confinement of the sediment into cells was revealed by the bottom grid structure (BGS) (He \& Marsalek, 2013). Cellular confinement cells (geocell) were developed by the US Army Corps of Engineers Caltrans (Caltrans, 2006) to provide soil stabilization, which is a much different solution from BGS presented by He et al. (2014). Simpson et al. (2018) prevented the amount of resuspended sediment by using cellular confinement cells, one of the specific geotextile products, of different sizes in their study. 
When the literature is examined, no studies have been encountered on the prevention of local scour with geocell. In this study, the effect of geocell on the scouring was investigated for the first time. This investigation aims to measure the effectiveness of a geocell as a means to prevent scour in downstream of the spillway. The honeycomb shape characteristic of geocell was used for experiments. Experiments were conducted for three different cell depths, four different flow rates, and two different tailwater levels. Also, the temporal scour was also investigated.

\section{DIMENSIONAL ANALYSIS}

As shown in Figure 1, equilibrium phase depth of the scour $\left(Z_{\max }\right)$ can be written as a function of cell depth $(H)$, width of chute channel $\left(b_{y}\right)$, width of apron $(B)$, tailwater depth $\left(h_{t w}\right)$ mass density of the water $(\rho)$, mass density of the bed material $\left(\rho_{s}\right)$, average velocity of flow at downstream end of chute channel $(U)$, streamwise distance from the stilling basin end of the maximum scour $\left(X_{s}\right)$, median grain size $\left(d_{50}\right)$, flow depth at downstream end of chute channel $\left(h_{0}\right)$, and the gravitational acceleration $(g)$.

$$
Z_{\max }=f_{1}\left(H, b_{y}, B, X_{s}, h_{t w}, \rho, \rho_{s}, U, d_{50}, h_{0}, g\right)
$$

In sediment-water interaction, it is appropriate to represent the independent parameters $g, \rho$, and $\rho_{s}$ as a combined parameter, modifying gravitational acceleration $\Delta g$ (Oliveto \& Comuniello; 2009).

$$
\mathbf{F}_{d}=\frac{U}{\left(\Delta g d_{50}\right)^{1 / 2}}=\frac{U}{\left(g d_{50}\left(\rho_{s}-\rho\right) / \rho\right)^{1 / 2}}
$$

where $\mathbf{F}_{d}$ is densimetric Froude number. Applying the Buckingham $\pi$ theorem, dimensionless equations in functional forms can be obtained as follows:

$$
\frac{Z_{\max }}{H}=f_{2}\left(\mathbf{F}_{d}, \frac{b_{y}}{H}, \frac{B}{H}, \frac{h_{t w}}{H}, \frac{d_{50}}{H}, \frac{X_{s}}{H}, \frac{h_{0}}{H}\right)
$$

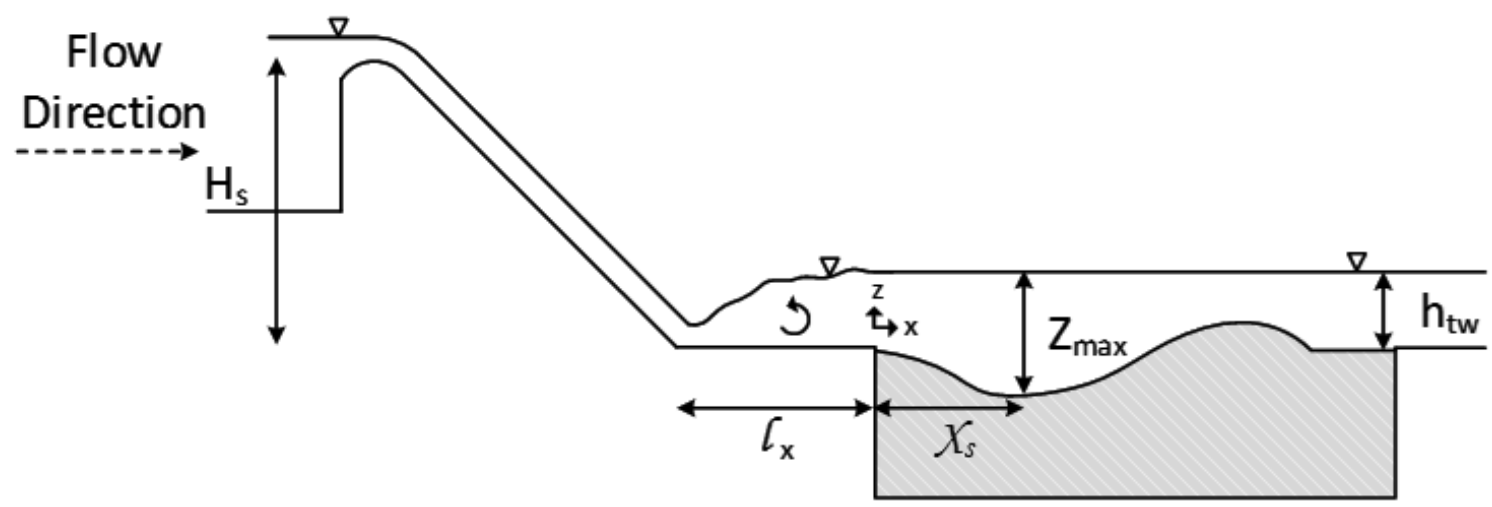

Figure 1. Experimental setup (not to scale).

\section{MATERIAL and METHODS MODEL SETUP}

The experiments were conducted at the Hydraulic Laboratory of Inonu University, using a $2.5 \mathrm{~m}$ head $\left(H_{s}\right)$ and $0.4 \mathrm{~m}$ width of the ogee crest shaped chute channel $\left(b_{y}\right)$. The flowing water in the chute channel (Figure 1), with an angle of $50^{\circ}$ to the horizontal plane, transmitted a $0.40 \mathrm{~m}$ extended $\left(l_{x}\right) 1 \mathrm{~m}$ width $(B)$ into an apron. Dimensions are selected so that there is no scale effect. Arkon flow system, an electromagnetic flow meter with an accuracy of $\pm 2 \%$, was used to measure discharge. The water depth on the ogee crest and maximum scour depth were measured by point 
gauge, Mitutoyo brand, with accuracy to the nearest millimeter. The water cycle is provided by the centrifugal pump, with a power of $7.5 \mathrm{~kW}$.

The bed material was nearly uniformly graded sandy soil; the values of geometric standard deviations begin less than 1.4. The bed material median grain size $d_{50}=2.41 \mathrm{~mm}$ and sediment gradation $\sigma=\left(d_{84} / d_{16}\right)^{1 / 2}=2.18$. The particle size distribution of the sandy soil is shown in Figure 2. The characteristics of the sandy soil determined through testing program that consisted of a combination of laboratory tests were given in Table 1.

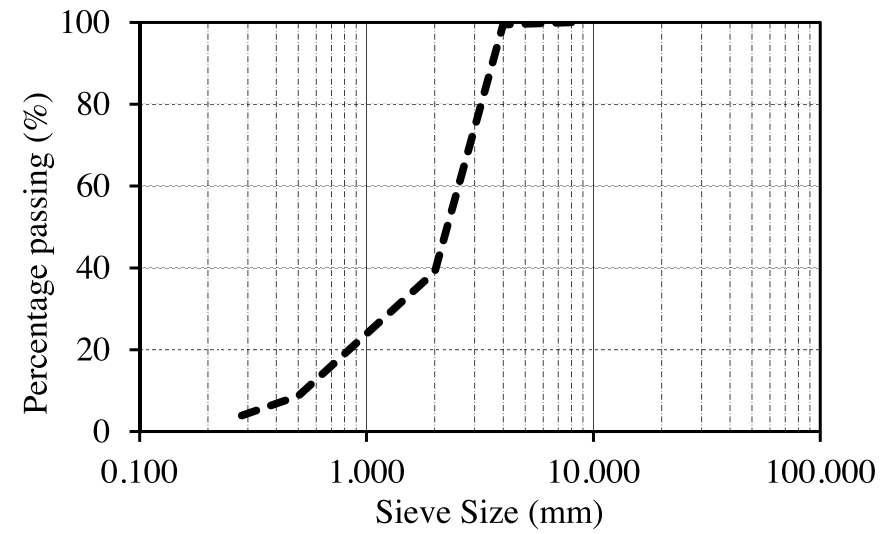

Figure 2. Particle size distribution for sandy soil.

Table 1. The characteristics of the sandy soil.

\begin{tabular}{|c|c|c|c|}
\hline Parameter & Symbol & Unit & Value \\
\hline Specific gravity & $\mathrm{G}_{\mathrm{s}}$ & - & 2.55 \\
\hline Maximum dry unit weight & $\gamma_{\mathrm{kmax}}$ & $\mathrm{kN} / \mathrm{m}^{3}$ & 18.47 \\
\hline Minimum dry unit weight & $\gamma_{\mathrm{kmin}}$ & $\mathrm{kN} / \mathrm{m}^{3}$ & 15.89 \\
\hline Angle of internal friction at dry state & $\phi$ & Degree & 29.8 \\
\hline Angle of internal friction at saturated condition & $\phi$ & Degree & 28.2 \\
\hline D10 & - & $\mathrm{mm}$ & 0.53 \\
\hline D50 & & $\mathrm{mm}$ & 2.41 \\
\hline D60 & - & $\mathrm{mm}$ & 2.55 \\
\hline D85 & - & $\mathrm{mm}$ & 3.35 \\
\hline D90 & & $\mathrm{mm}$ & 3.63 \\
\hline Uniformity coefficient & $\mathrm{C}_{\mathrm{u}}$ & - & 4.81 \\
\hline Coefficient of curvature & $\mathrm{C}_{\mathrm{c}}$ & - & 1.66 \\
\hline Soil Classification & - & - & $\mathrm{SP}$ \\
\hline
\end{tabular}

The raw material of geocell has high density polyethylene, and the polymer density is between 0.935 and 0.965 $\mathrm{g} / \mathrm{cm}^{3}$. Geocell thickness is $0.2 \mathrm{~m}$, and tensile strength and seam strength are $12 \mathrm{kN} / \mathrm{m}$. The properties of the geocell used for the strengthening of the ground are supplied by the manufacturer (Geoplas). The geocell used in experimental studies has a total width of $1 \mathrm{~m}$ and a total length of $2 \mathrm{~m}$. The weld interval range of geocell with honeycomb geometry is $25 \mathrm{~cm}$. 


\section{EXPERIMENTAL MEASUREMENTS}

All experimental runs, a total of 24, are reported in Table 2. Experiments were conducted for four different flow rates, three different geocell depths, and two different tailwater levels. Each test was run for six hours, which was sufficient for most of the tests to reach an equilibrium phase of scouring. All the surveys were performed after the flow was ended and drained. Tailwater depths were measured at about $2.5 \mathrm{~m}$ downstream of the apron. Geocell with a depth of cell 5, 10, and $15 \mathrm{~cm}$ is shown as $\mathrm{H} 5, \mathrm{H} 10$, and $\mathrm{H} 15$, respectively.

The maximum depth of the scour $\left(Z_{\max }\right)$, the nap height on the ogee crest $\left(h_{0}\right)$, and the distance of the scour from the apron $\left(X_{s}\right)$ were measured for each series of experiments. Because optimum results were obtained for geocell, which has a cell depth of $15 \mathrm{~cm}$, the experiments at H15 cell depth were conducted for up to 72 hours, and the timedependent scour changes were examined. Also, at this cell depth, depth and location of scouring were investigated with two different tailwater depths.

To conduct unreinforced test, firstly, a scour tank with a bed material of $50 \mathrm{~cm}$ depth was formed. Following the control of bed material level and surface slope, unreinforced tests were conducted. Secondly, a scour tank with a total depth of $50 \mathrm{~cm}$ depth (the depth of the bed material was selected for three different geocell depths) was determined for reinforced tests.

The geocell elevation was the same as the apron. Also, geocell is horizontal and has zero slope. After the geocell was placed, the cells were filled with bed material. After filling each cell with bed material and checking all parameters, the tests were carried out (Figure 3). In all of the experiments, it was noted that the bed material had the same compression ratio.

Table 2. Experimental Conditions.

\begin{tabular}{|c|c|c|c|c|c|c|}
\hline $\begin{array}{c}\text { Test } \\
\text { No }\end{array}$ & $\begin{array}{c}H \\
(\mathrm{~cm})\end{array}$ & $\begin{array}{c}Q \\
(\mathrm{lt} / \mathrm{s})\end{array}$ & $\begin{array}{c}h_{0} \\
(\mathrm{~cm})\end{array}$ & $\begin{array}{c}h_{t w} \\
(\mathrm{~cm})\end{array}$ & $\begin{array}{c}X_{s} \\
(\mathrm{~cm})\end{array}$ & $\begin{array}{c}Z_{\max } \\
(\mathrm{cm})\end{array}$ \\
\hline 1 & 15 & 20 & 6 & - & 114 & 11.55 \\
\hline 2 & 15 & 5 & 2.2 & - & 30 & 8.05 \\
\hline 3 & 15 & 15 & 4.7 & - & 90 & 9.55 \\
\hline 4 & 15 & 10 & 3.5 & - & 17 & 9.05 \\
\hline 5 & 10 & 10 & 3.5 & - & 18 & 10.05 \\
\hline 6 & 10 & 20 & 6 & - & 28 & 12.05 \\
\hline 7 & 10 & 5 & 2.2 & - & 29 & 9.45 \\
\hline 8 & 10 & 15 & 4.7 & - & 29 & 9.65 \\
\hline 9 & 5 & 20 & 6 & - & 90 & 16.05 \\
\hline 10 & 5 & 15 & 4.7 & - & 35 & 9.45 \\
\hline 11 & 5 & 10 & 3.5 & - & 36 & 6.55 \\
\hline 12 & 5 & 5 & 2.2 & - & 25 & 6.05 \\
\hline 13 & 0 & 20 & 6 & - & 140 & 18.15 \\
\hline 14 & 0 & 15 & 4.7 & - & 134 & 16.20 \\
\hline 15 & 0 & 5 & 2.2 & - & 53 & 10.05 \\
\hline 16 & 0 & 10 & 3.5 & - & 84 & 11.10 \\
\hline 17 & 15 & 20 & 6 & 15 & 2 & 10.05 \\
\hline 18 & 15 & 20 & 6 & 20 & 9 & 9.95 \\
\hline 19 & 15 & 15 & 4.7 & 15 & 2 & 9.55 \\
\hline 20 & 15 & 15 & 4.7 & 20 & 25 & 8.75 \\
\hline 21 & 15 & 10 & 3.5 & 15 & 18 & 7.55 \\
\hline 22 & 15 & 10 & 3.5 & 20 & 25 & 6.65 \\
\hline 23 & 15 & 5 & 2.2 & 15 & 15 & 6.05 \\
\hline 24 & 15 & 5 & 2.2 & 20 & 15 & 4.75 \\
\hline & & & & & & \\
\hline
\end{tabular}




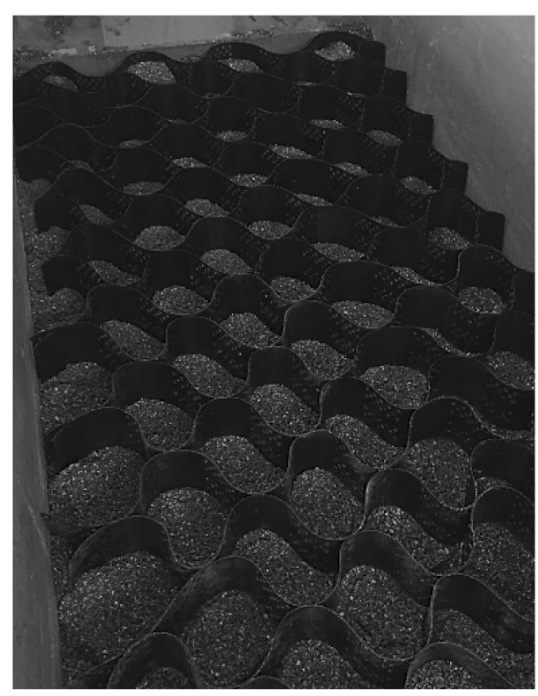

(a)

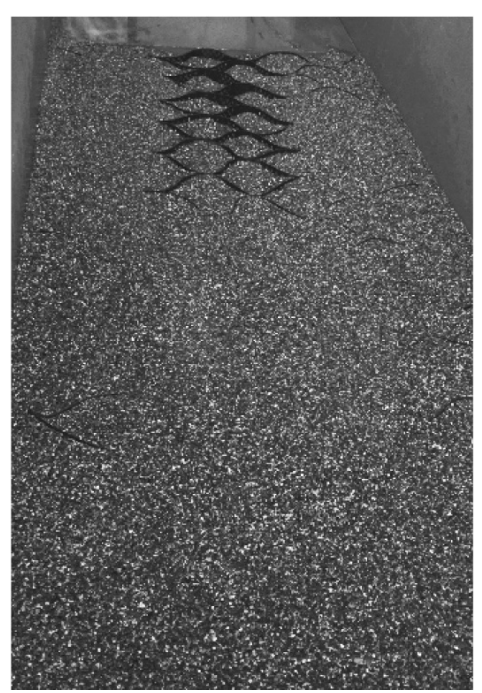

(b)

Figure 3. Experimental setup before (a) and after the local scour (b).

\section{RESULT and DISCUSSION}

The idea of placing a geocell reinforcement into the bed material was investigated for local scour protection. In addition, the cycle movement of sand grain within the cells was observed in detail. The maximum local scour depth with flow rate changes for unreinforced (UR) and reinforced (RF) condition is shown in Figure 4.

For all experimental series, the use of the geocell reduced the maximum local scour depth. Especially, in smaller flow rates, the geocell with $\mathrm{H} 5$ depth showed the best performance. The horizontal movement of geocell was observed at the geocell with H5 for 15 and 20 L/s. No horizontal movement of geocell occurred for all flow rates at H10 and H15.

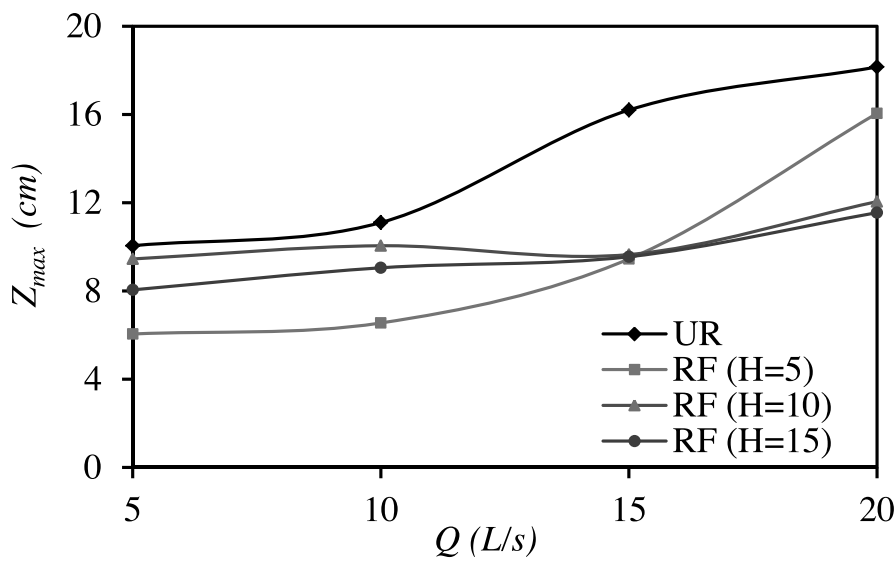

Figure 4. The maximum local scour depth with flow rate change for unreinforced (UR) and reinforced $(\mathrm{RF})$ conditions. 
The effect of tailwater on geocell reinforced bed material is shown in Figure 5. The tailwater provided a linear change of the maximum scour depth. In addition, the tailwater significantly reduced the maximum scour depth.

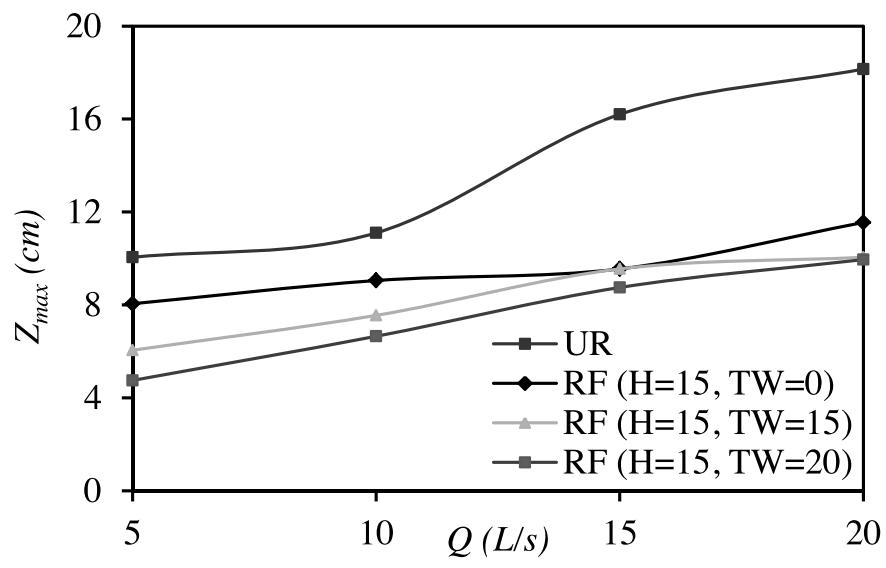

Figure 5. The maximum local scour depth with flow rate for different tailwater.

Figure 6 shows that the number of $F_{d}$ is not proportional to the change of relative scour depth. In particular, H10 and $\mathrm{H} 5$ geocells show the same performance for $\mathrm{F}_{\mathrm{d}}=0.363883$. Although $\mathrm{H}$ values increase at the same rate, maximum scour values are distributed evenly for $\mathrm{F}_{\mathrm{d}}=0.4000272$ only.

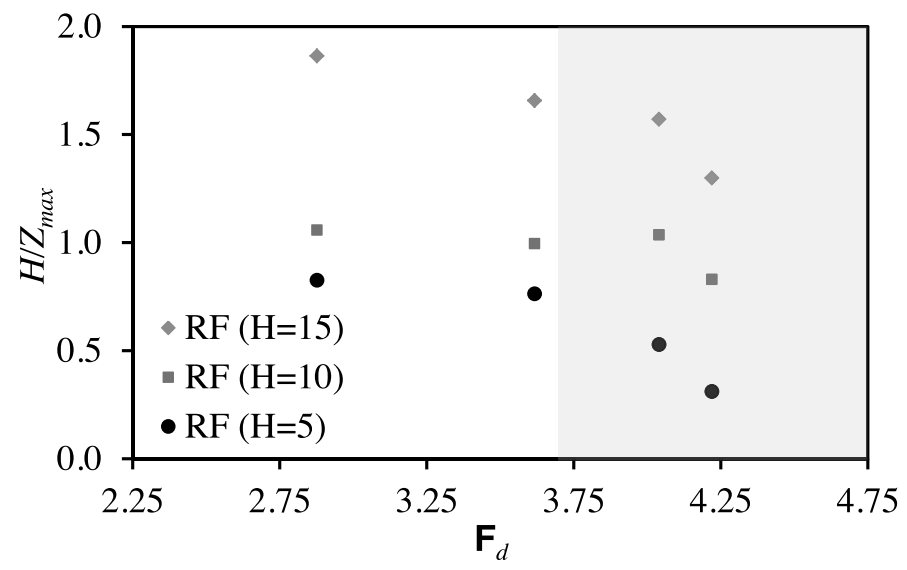

Figure 6. Relative maximum scour depth for varying densimetric Froude number $\left(\mathbf{F}_{d}\right)$.

\section{TEMPORAL SCOUR VARIATION}

The most optimal results in all flow values, the H15, were maintained for up to 12 hours. It is seen that the time with $6 \mathrm{~h}$ is the equilibrium phase for all the flow rates. The time-dependent scour change is shown in Figure 7. 


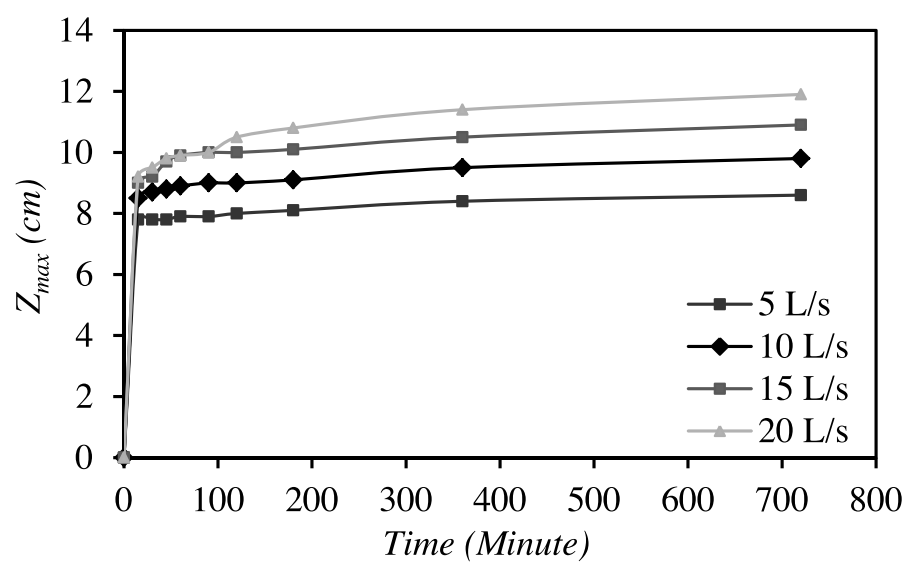

Figure 7. Temporal the extreme scour variation.

\section{DISSIPATION EFFICIENCY}

Scour phenomenon is directly related to the energy that water has. Geocell placed on the bed significantly limits the moving of the bed materials. The velocity vectors that move into the cell provide movement of the grains. When the energy of the water enters each cell, it decreases slightly (Figure 8b).

In the conducted experiments, different scour geometries were observed in each cell. The slope in the cell is seen to increase from the upstream to the downstream. Geocell placed on the ground served as a reinforcement of the bed. In case of unreinforced condition, it was observed that the scouring topography was formed at certain points, but when geocell was reinforced, it was observed that a uniformly scouring topography was formed in all cells (Figure 8a).

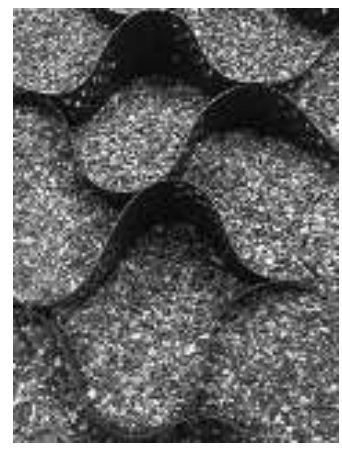

(a)

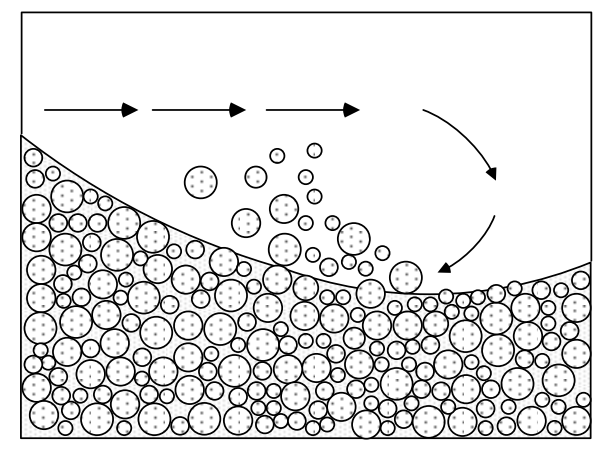

(b)

Figure 8. Definition sketch: (a) local scour geometry and view of the scour of the slope in the different spatial cell for H15; (b) scour mechanism in the cell.

Flow rates of $15-20 \mathrm{~L} / \mathrm{s}$ and 5-10 L/s showed the same trends. $\mathrm{H} 15$ has shown the best performance by reducing the scour rate by $40.63 \%$ (Figure 9.). The percentage reduction of the scour (PRS) was calculated by equation 4 . It was thought that maximum scour depth that occurs in unreinforced condition is important for determining the geocell depth to be selected. High flow rates represent high densimetric Froude numbers, thus high energy. With higher densimetric Froude numbers, the expected maximum scour value is greater. In Figure 9, it can be concluded that deeper geocells are suitable for large maximum scour values, and smaller geocell depths are suitable for small scour depths. All densimetric Froude numbers were found to perform well at smaller geocell depths. This indicates 
the strong relationship between the value of the maximum scour depth $\left(Z_{\max }\right)$ created by the unreinforced (UR) scour requirement and the geocell depth. While the maximum scour depths $\left(Z_{\max }\right)$ created by high flow rates are closer to the geocell depths, the opposite is true for lower flow rates. This study showed that the depth of geocell should be less than the maximum scour value that occurs under unreinforced condition (UR). Also, the pioneer of the scour protection and strong cause and effect relationships can be revealed by detailed examination of the velocity fields that may occur in the geocells.

$$
P R S=\frac{H_{U R}-H_{R}}{H_{U R}} \times 100
$$

where $H_{U R}$ is the maximum scour depth for the unreinforced ground, and $H_{R}$ is the maximum scour depth for the reinforced ground.

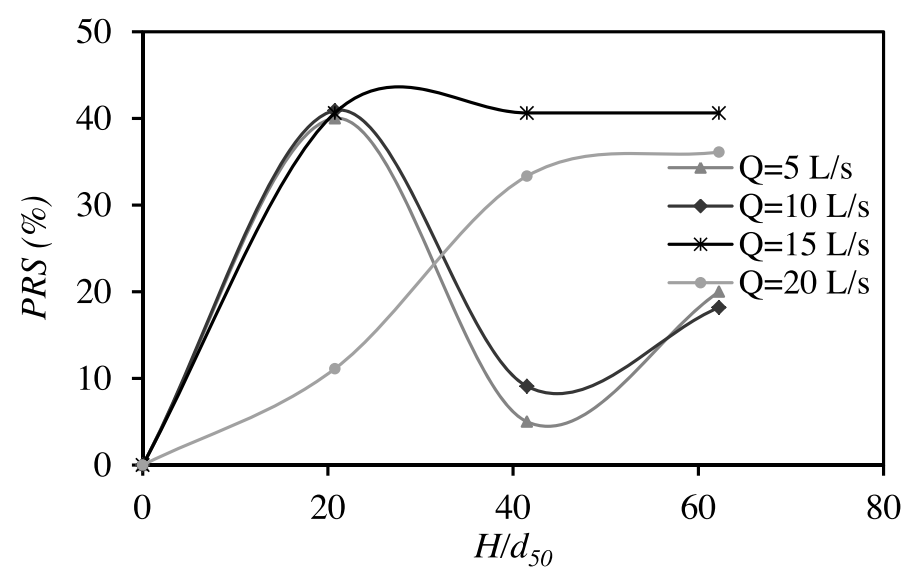

Figure 9. Percentage Reduction of the Scour (PRS) for varying relative depths.

\section{SPATIAL CHANGE of the LOCAL SCOUR}

For reinforced geocell (RF) and unreinforced geocell (UR) experiments, the maximum local scour points were determined. These spatial changes are shown for all flow rates (Figure 10.). It is determined that $X_{s}$ decreases in case of reinforcement geocell for all flow values.

Determining the depth and position of scouring is an important design problem. Nonlinear multiple regression was applied to the experimental data to obtain the fit scour depth equation. An equation that gives the scour value according to the nap height of the spillway is derived from the experimental data (Equation 5). The correlation coefficient $\left(R^{2}\right)$ was determined as 0.81 . Although the depths of geocell change equally, the median values showed that the scouring was concentrated in one part (Figure 11.).

$$
\frac{H}{Z_{\max }}=0.5072\left(\frac{H}{h_{0}}\right)^{0.7426}
$$




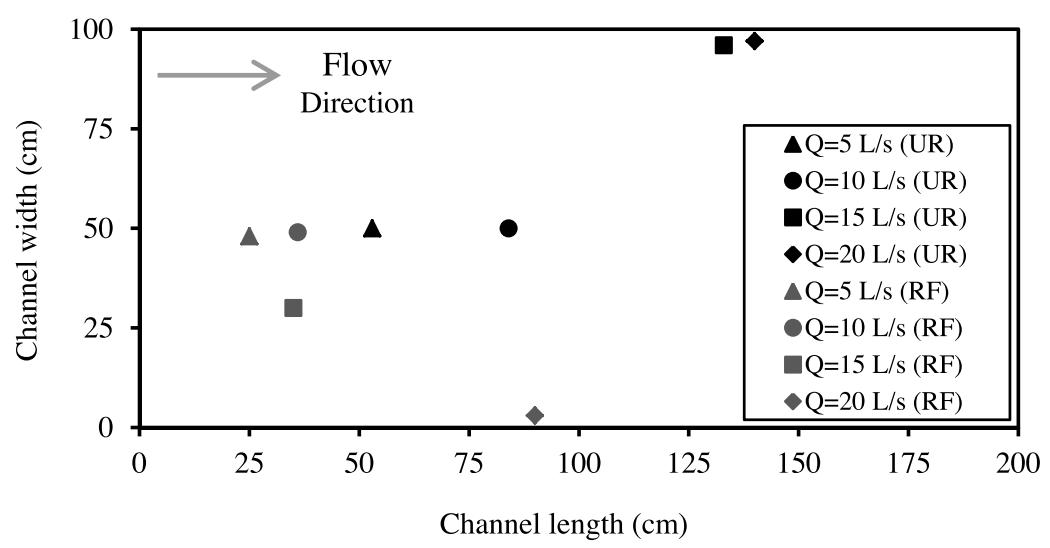

(a)

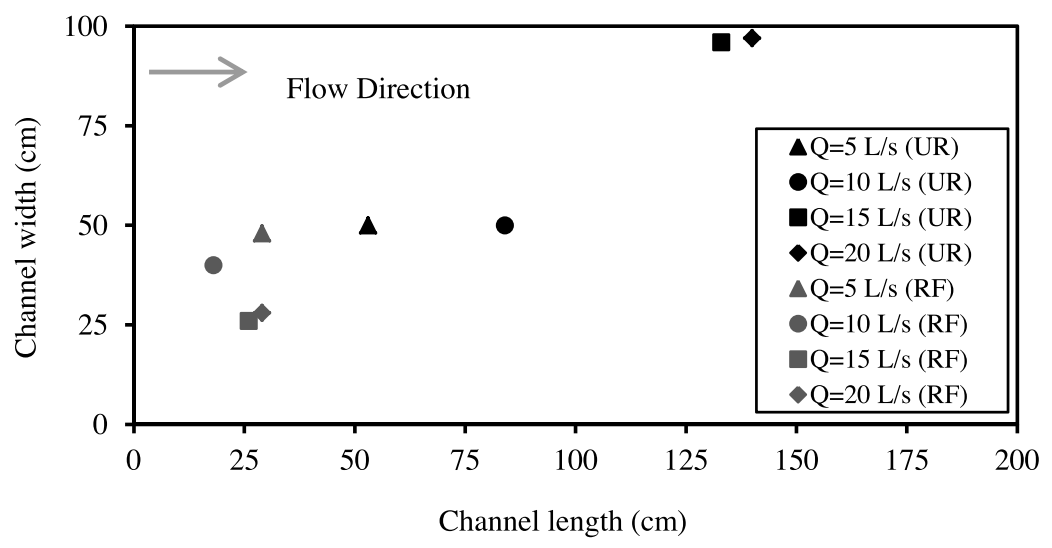

(b)

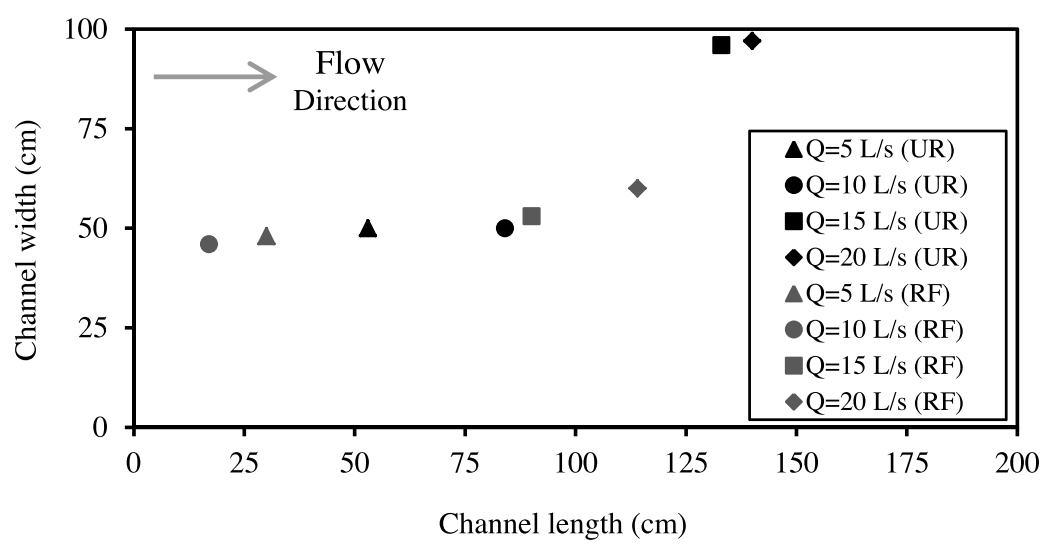

(c)

Figure 10. Spatial distribution of maximum local scour depth: (a) H5, (b) H10, and (c) H15. 


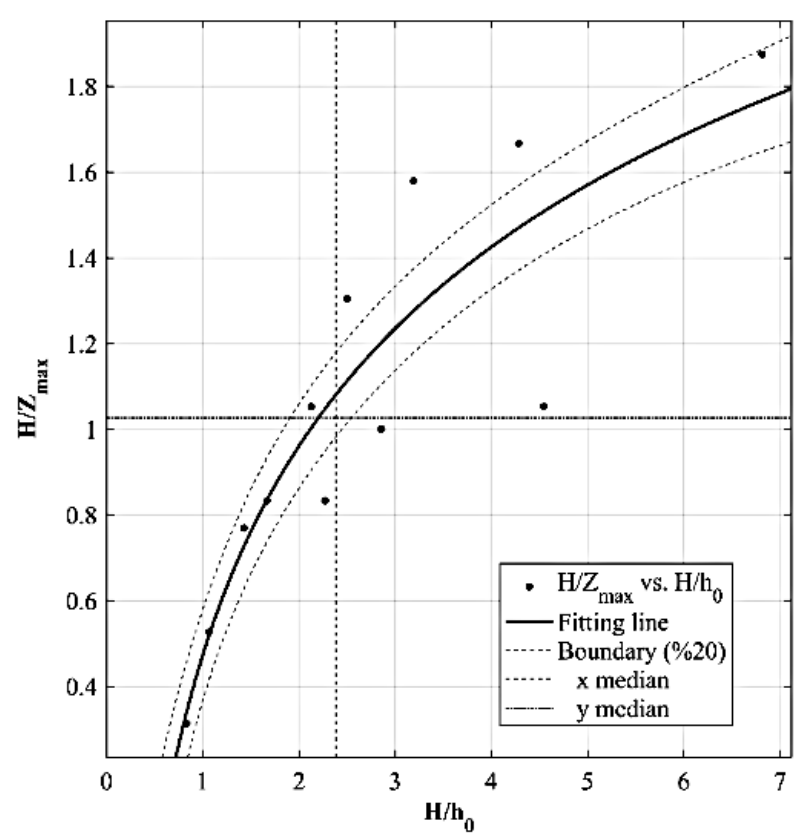

Figure 11. Relative maximum scour depth for varying relative nap depth.

\section{CONCLUSION}

In recent years, climate change ensures that the planning criteria of hydraulic structures remain incomplete. Especially, in situations such as overflowing and flood, extremely large scour behaviors can occur. Therefore, the protection of the scour downstream of hydraulic structures is increasingly important. The experimental study of the countermeasure of the local scour with and without geocell reinforcement led to the following conclusions.

- Use of the geocell reduced local scour in the downstream of the spillways for all of the densimetric Froude numbers.

- The effect of different geocell depths was examined. The strong relationship between geocell depths and maximum scour depth was determined, and the equation was proposed. With the best performance, scouring was prevented by $40.63 \%$. The maximum scour depth performance of the geocell with $5 \mathrm{~cm}$ depth is extremely good at small flow rates, while the $15 \mathrm{~cm}$ depth one is good for large flows.

- It was thought that maximum scour depth that occurs in unreinforced condition is important for determining the geocell depth to be selected. Deeper geocells are suitable for large maximum scour values, and smaller geocell depths are suitable for small scour depths. This indicates the strong relationship between the value of the $Z_{\max }$ created by the UR scour requirement and the geocell depth. While the $Z_{\max }$ created by high flow rates are closer to the geocell depths, the opposite is true for lower flow rates. This study showed that the depth of geocell should be less than the maximum scour value that occurs under UR condition. Also, the pioneer of the scour protection and strong cause and effect relationships can be revealed by detailed examination of the velocity fields that may occur in the geocells.

- The spatial distribution of maximum local scour depth was examined. It was determined that the position of the maximum scour depth in the streamwise is closer to the stilling basin end in the state reinforced with geocell.

- In addition, two different tailwater depth conditions were examined. It was observed that the depth of the tailwater could help prevent scour. 


\section{ACKNOWLEDGMENT}

This study was supported by a grant from Inonu University (Project number: İÜ-BAP, FCD-2018-1324).

\section{REFERENCES}

Amini, N., Balouchi, B., \& Bejestan, M.S. 2017. Reduction of local scour at river confluences using a collar. International Journal of Sediment Research, 32(3): 364-372.

Balachandar, R., Kells, J.A., \& Thiessen, R.J. 2000. The effect of tailwater depth on the dynamics of local scour. Canadian Journal of Civil Engineering, 27(1): 138-150.

Ben Meftah, M., \& Mossa, M. 2006. Scour holes downstream of bed sills in low-gradient channels. Journal of Hydraulic Research, 44(4): 497-509.

Bejestan, M.S., Khademi, K., \& Kozeymehnezhad, H. 2015. Submerged vane-attached to the abutment as scour countermeasure. Ain Shams Engineering Journal, 6(3): 775-783.

Borghei, S.M., \& Sahebari, A.J. 2010. Local scour at open-channel junctions. Journal of Hydraulic Research, 48(4): 538-542.

Caltrans - State of California Department of Transportation 2006. Cellular Confinement System Research. Report CTSW-RT06-137.20.1.

Champagne, T.M., Barkdoll, B.D., \& González-Castro, J.A. 2017. Experimental Study of Scour Induced by Temporally Oscillating Hydraulic Jump in a Stilling Basin. Journal of Irrigation and Drainage Engineering, 143(12): 04017051.

Coleman, S.E., Lauchlan, C.S., \& Melville, B.W. 2003. Clear-water scour development at bridge abutments. Journal of Hydraulic Research, 41(5): 521-531.

Farhoudi, J., \& Shayan, H.K. 2014. Investigation on local scour downstream of adverse stilling basins. Ain Shams Engineering Journal, 5(2): 361-375.

Grimaldi, C., Gaudio, R., Calomino, F., \& Cardoso, A.H. 2009. Countermeasures against local scouring at bridge piers: slot and combined system of slot and bed sill. Journal of Hydraulic Engineering, 135(5): 425-431.

Hamidifar, H., Nasrabadi, M., \& Omid, M.H. 2017. Using a bed sill as a scour countermeasure downstream of an apron. Ain Shams Engineering Journal, 9(4): 1663-1669.

He, C., \& Marsalek, J. 2013. Enhancing sedimentation and trapping sediment with a bottom grid structure. Journal of environmental engineering, 140(1): 21-29.

He, C., Post, Y., Rochfort, Q., \& Marsalek, J. 2014. Field study of an innovative sediment capture device: bottom grid structure. Water, Air, \& Soil Pollution, 225(6): 1976.

Heibaum, M.H. 2000. Scour countermeasures using geosynthetics and partially grouted riprap. Transportation research record, 1696(1): $244-250$.

Hoffmans, G.J., \& Pilarczyk, K.W. 1995. Local scour downstream of hydraulic structures. Journal of Hydraulic Engineering, 121(4): 326-340.

Khosravinia, P., Malekpour, A., Hosseinzadehdalir, A., \& Farsadizadeh, D. 2018. Effect of trapezoidal collars as a scour countermeasure around wing-wall abutments. Water Science and Engineering, 11(1): 53-60.

Kim, U.Y., Park, H., \& Yoo, K.H. 2000. Local scour countermeasure around bridge piers. WIT Transactions on Ecology and the Environment, 45.

Koochak, P., \& Bajestan, M.S. 2016. The effect of relative surface roughness on scour dimensions at the edge of horizontal apron. International Journal of Sediment Research, 31(2): 159-163.

Korkut, R., Martinez, E.J., Morales, R., Ettema, R., \& Barkdoll, B. 2007. Geobag performance as scour countermeasure for bridge abutments. Journal of Hydraulic Engineering, 133(4): 431-439.

Li, H., Barkdoll, B.D., Kuhnle, R., \& Alonso, C. 2006. Parallel walls as an abutment scour countermeasure. Journal of Hydraulic Engineering, 132(5): 510-520. 
Li, H., Barkdoll, B., \& Kuhnle, R. 2005. Bridge abutment collar as a scour countermeasure. In Impacts of Global Climate Change (pp. 1-12).

Mason, P.J., \& Arumugam, K. 1985. Free jet scour below dams and flip buckets. Journal of Hydraulic Engineering, 111(2): 220235.

Nik Hassan, N.M.K., \& Narayanan, R. 1985. Local scour downstream of an apron. Journal of Hydraulic Engineering, 111(11): 1371-1384.

Oliveto, G., \& Comuniello, V. 2009. Local scour downstream of positive-step stilling basins. Journal of Hydraulic Engineering, 135(10): 846-851.

Pagliara, S., Palermo, M., \& Carnacina, I. 2011. Scour process due to symmetric dam spillways crossing jets. Intl. J. River Basin Management, 9(1): 31-42.

Palermo, M., \& Pagliara, S. 2018. Effect of unsteady flow conditions on scour features at low-head hydraulic structures. Journal of Hydro-environment Research, 19: 168-178.

Radice, A., \& Davari, V. 2014. Roughening elements as abutment scour countermeasures. Journal of Hydraulic Engineering, 140(8): 06014014.

Simpson, T., Wang, J., \& Vasconcelos, J.G. 2018. Cellular Confinement Systems to Prevent Resuspension in Sediment Basins. Journal of Environmental Engineering, 144(5): 04018024.

Tuna, M.C., \& Emiroglu, M.E. 2011. Scour profiles at downstream of cascades. Scientia Iranica, 18(3): 338-347.

Yun, D.H., \& Kim, Y.T. 2018. Experimental study on settlement and scour characteristics of artificial reef with different reinforcement type and soil type. Geotextiles and Geomembranes, 46(4): 448-454.

Zarrati, A.R., Chamani, M.R., Shafaie, A., \& Latifi, M. 2010. Scour countermeasures for cylindrical piers using riprap and combination of collar and riprap. International Journal of Sediment Research, 25(3): 313-322. 